\title{
Hubungan antara Dukungan Sosial Keluarga dengan Penerimaan Diri Pada Santri Pondok Pesantren
}

\author{
Zulmi wahyuningsih, Mujidin, Yuzarion \\ Fakultas psikologi Universitas Ahmad Dahlan \\ Email: zulmizhizhi@gmail.com, mujidin zia@yahoo.co.id, yuzarion@psy.uad.ac.id
}

\begin{abstract}
Abstact
The purpose of this study was to determine the relationship between family social support and self-acceptance in Islamic boarding school students. This research is a quantitative study with a cluster random sampling technique, with a total of 112 subjects who attend Islamic boarding schools in Tidore archipelago. Data collection in this study used a self-acceptance scale and a family social support scale. The analytical method used is a statistical method with product moment analysis techniques based on the IBM SPSS 23.0 for windows program. The results in this study indicate a very significant relationship between family social support and self-acceptance of Islamic boarding school students, indicated by a value of $r=0.673 p=0.000$ ( $p$ $<0.01)$ the higher the family social support, the higher the self-acceptance of Islamic boarding school students.
\end{abstract}

Keywords: boarding school, social support, self-acceptance

\begin{abstract}
Abstrak
Tujuan dari penelitian ini untuk mengetahui hubungan dukungan sosial keluarga terhadap penerimaan diri pada santri pondok pesantren. Penelitian ini adalah penelitian kuantitatif dengan teknik pengambilan sampel cluster random sampling, dengan jumlah subjek 112 orang yang bersekolah di pondok pesantren di Tidore kepulauan. Pengumpulan data pada penelitian ini menggunakan skala penerimaan diri dan skala dukungan sosial keluarga. Metode analisis yang digunakan adalah metode statistik dengan teknik analisis product moment yang berbasis program SPSS IBM 23.0 for windows. Hasil pada penelitian ini menunjukan adanya hubungan yang sangat signifikan antara dukungan sosial keluarga dan penerimaan diri pada santri pondok pesantren ditunjukan dengan nilai $r=0,673 \mathrm{p}=0.000(\mathrm{p}<0.01)$ semakin tinggi dukungan sosial keluarga maka semakin tinggi juga penerimaan diri pada santri pondok pesantren
\end{abstract}

Kata kunci: pondok pesantren,dukungan sosial keluarga, penerimaan diri

\section{Pendahuluan}

Santri yang terbiasa tinggal di rumah dan hidup bergantung kepada orang tua kemudian dituntut untuk tinggal di pondok pesantren sehingga santri harus menerima keadaan yang tidak diharapkan, santri harus merubah kebiasaan hidup yang sebelumnya dan harus beradaptasi kembali pada dengan kehidupan sehari-hari yang sudah berbeda misalnya dalam pengambilan keputusan, menyelesaikan masalah dan menyelesaikan tanggung jawab sebagai seorang santri, ketika santri sudah diberikan suatu pilihan maka santri tersebut diharapkan mampu menerimanya. Kehidupan di pondok pesantren biasa dilakukan dengan pola kedisiplinan dengan kegiatan yang dilakukan setiap hari dan santri diwajibkan menaati peraturan yang ditetapkan didalam pesantren tersebut. Santri dituntut untuk bisa mengatur hidupnya sendiri sesuai dengan peraturan yang berlaku di pesantren mulai dara cara mengatur kegiatan ibadah sehari-hari, pola makan, waktu belajar, bersaing dalam bidang akademis dengan temantemannya, sehingga santri akan menghadapi berbagai masalah psikologis dan masalah sosial yang dihadapi di pesantren. Tekanan dari keadaan inilah yang membuat para santri sulit menerima dirinya sebagai seorang santri dengan berbagai macam tuntunan dan kewajiban yang harus dilakukan. Santri pada usia remaja merupakan masa transisi antara masa kanak-kanak menuju masa dewasa, dimana masa remaja memiliki kematangan emosi, sosial, fisik dan psikis. Remaja juga merupakan tahapan perkembangan yang harus dilewati dengan berbagai kesulitan, menurut Santrock [1] masa remaja diwarnai oleh interaksi antara faktor-faktor genetik, biologis, lingkungan dan sosial. Usia remaja menurut Santrock usia 10 hingga 13 dan berakhir pada usia sekitar 18 hingga 22 tahun. Dalam perkembangan sehari-hari remaja membutuhkan penerimaan diri agar remaja tersebut memahami tentang dirinya sendiri, termasuk mengenali akan kelemahan dan kelebihan yang ada pada dirinya. Penerimaan diri merupakan salah satu gambaran dari perkembangan dan sebagai suatu kewajiban manusia agar dapat menjalani kehidupannya, karena menerima diri berarti menerima akan keadaan

Diterima Redaksi : 16-10-2020 | Selesai Revisi : 27-04-2021 | Diterbitkan Online : 28-04-2021 
dirinya dan lingkungan disekitarnya, sehingga remaja terutama santri diharapkan akan mampu menyesuaikan dan menyelesaikan pada setiap peristiwa atau permasalahan dalam kehidupannya.

Individu yang memiliki penerimaan diri adalah individu yang mempertahankan harapan dan tuntutan dari dalam dirinya dengan baik, yang memungkinkan individu ini memiliki ambisi besar, namun tidak mungkin untuk mencapainya sekalipun dalam jangka waktu yang lama dan akan menghabiskan energinya [2]. Selama berada di pondok pesantren, santri akan dihadapkan dengan berbagai permasalahan ataupun persoalan, dan ketika mereka mampu menghadapi dan menyelesaikan permasalahan itu akan menjadikan suatu potensi dalam diri individu tersebut lebih berkembang. Beberapa kasus ketika santri berada dalam lingkungan pesantren banyak teman-teman dari berbagai daerah dan memiliki kemampuan akademik yang berbeda-beda sehingga menimbulkan persaingan antara santri yang membuat beberapa santri tidak percaya diri atas kemampuan yang dimiliki dan menjadikan santri tidak bisa menerima dirinya sebagai santri atau individu yang memiliki kelemahan ataupun kelebihan pada dirinya.

Faktor yang mempengaruhi penerimaan diri Hurlock salah satunya adalah bebas dari hambatan lingkungan, artinya banyak harapan individu tidak tercapai disebabkan dari lingkungan yang tidak mendukung. Hambatan dari lingkungan ini berasal dari orang tua, guru, teman sebaya dan orang dekat lainnya. Penerimaan diri akan dapat terwujud apabila lingkungan dimana individu berada memberikan dukungan yang penuh [3]. Taylor mengemukakan bahwa, dukungan sosial sebagai informasi dari orang lain berupa cinta dan kasih sayang, dan bagian dari sebuah jaringan komunikasi dan kewajiban bersama [4]. Dukungan sosial merupakan suatu keadaan yang bermanfaat bagi individu yang diperoleh dari orang lain yang dapat dipercaya yang membuat individu merasa bahwa dirinya dihormati, dihargai, dicintai dan dapat diterima oleh orang lain. Adanya dukungan dari keluarga atas keputusan dan rencana yang disusun oleh santri atau individu dapat mebuat santri lebih fokus pada apa yang dikerjakan pada masa depan, dukungan dari keluarga berupa memberikan masukan-masukan mengenai pilihan yang mana yang paling baik untuk dilakukan dimasa yang akan datang. Dukungan dari orang tua juga menunjukan adanya suatu penghargaan dan kepercayaan kepada individu tersebut. Katc dan Kahn berpendapat bahwa dukungan sosial adalah suatu perasaan positif, menyukai, kepercayaan, dan perhatian dari orang lain yaitu orang yang berarti dalam kehidupan individu yang bersangkutan, pengakuan, kepercayaan seseorang dan bantuan langsung dalam bentuk tertentu [5].

Penelitian yang telah dilakukan menemukan bahwa terdapat hubungan yang positif antara dukungan sosial keluarga dengan penerimaan diri Hal tersebut menunjukkan bahwa semakin tinggi dukungan sosial keluarga maka semakin tinggi penerimaan diri individu [6]. Penelitian yang dilkukan oleh Sari dan Reza [7] menunjukkan koefisien korelasi sebesar 0,664 dengan nilai p (signifikan) sebesar 0,000 yang berarti terdapat hubungan yang bersifat positif atau selaras yang signifikan antara dukungan sosial dengan penerimaan diri. Hal ini menunjukkan bahwa semakin tinggi dukungan sosial maka semakin tinggi penerimaan diri dan sebaliknya semakin rendah dukungan sosial maka semakin rendah penerimaan diri remaja. Santri juga diharapakan untuk bisa melakukan penerimaan diri dan mendapatkan dukungan sosial dari keluarga, karena semakin baik santri tersebut mendapatkan dukungan sosial dari keluarga maka semakin baik juga santri dapat melakukan penerimaan dirinya.

\section{Penerimaan diri}

Penerimaan diri adalah sebagai kemampuan individu untuk dapat memiliki suatu pandangan positif mengenai siapa dirinya yang sebenar-benarnya, dan hal ini tidak dapat muncul dengan sendirinya, melainkan harus dikembangkan oleh individu [10]. penerimaan diri merupakan suatu tingkatan dimana individu akan benar-benar mempertimbangkan karakteristik kepribadinya dan mau hidup dengan karakteristik tersebut. Dengan penerimaan diri (self-acceptance), individu akan menghargai segala kelebihan dan kelemahan dalam dirinya[11]. Penerimaan diri adalah kemampuan untuk menerima diri sendiri tanpa syarat dan dapat menerima berbagai kesulitan-kesulitan emosional, termasuk kemaran yang tidak terkontri dan depresi [10]. Aspek-aspek penerimaan diri adalah sebagai berikut: a). Kemampuan dan kemauan untuk membiarkan orang lain melihat jati dirinya. Hidup dengan sadar berarti kehidupan sehari-hari tanpa kepura-puraan dan tanpa kekhawatiran bahwa orang lain menilai dirinya secara negatif. b) Evaluasi diri yang tepat. Evaluasi tersebut adalah pusat cara individu memahami diri sendiri dan kehidupan yang dijalani individu. Evaluasi diri yang berupa positif atau negatif adalah pilihan setiap individu dan individu tersebut dapat memilih untuk mengubah evaluasi 
perilaku apapun sesuai dengan konteks sehingga individu dapat menerima tindakan-tindakan yang bahkan menyebabkan rasa sakit dan individu juga dapat memilih untuk tidak mengulangi di masa depan. c) Pengambilan keputusan. Individu yang menerima tanggung jawab atas kehidupan pribadinya sendiri adalah bagian dari penerimaan diri. Tanggung jawab yang dimaksud adalah tanggung jawab dalam membuat dan mengambil keputusan. Individu harus menyadari bahwa keputusan yang diambil adalah keputusan sendiri bukan saran dari pemberi.

\section{Dukungan sosial keluarga}

Dukungan sosial adalah semua bentuk dukungan yang disediakan individu dan kelompok lain untuk membantu seseorang individu dalam mengatasi permasalahan individu tersebut[12]. Dukungan sosial adalah informasi dan umpan balik dari orang lain yang menunjukan bahwa seseorang dicintai dan diperhatikan, dihormati dan dilibatkan dalam komunikasi yang timbal balik [13]. Hal ini sejalan dengan Taylor [4] yang mendefinisikan dukungan sosial sebagai informasi dari orang lain berupa cinta dan kasih sayang,dan bagian dari sebuah jaringan komunikasi dan kewajiban bersama. Dukungan sosial keluarga mengacu pada bentuk dukungan sosial yang dikemukakan oleh Sarafino \& Smith [14] sebagai berikut: a) Dukungan emosional, dukungan emosional melibatkan rasa empati, ekspresi dan perhatian terhadap individu sehingga individu tersebut dapat merasa nyaman, dicintai dan diperhatikan. Dukungan emosional meliputi dukungan emosional meliputi perilaku seperti memberikan perhatian dan afeksi serta bersedia mendengarkan keluh kesah orang lain. b) Dukungan penghargaan, dukungan penghargaan melibatkan ungkapan hormat (penghargaan) positif untuk orang tersebut, dorongan maju atau persetujuan. c) Dukungan instrumental, bentuk dukungan instrumental melibatkan bantuan langsung, misalnya yang berupa bantuan finansial atau bantuan dalam mengerjakan tugas-tugas tertentu. d) Dukungan informasi, dukungan yang bersifat informasi dapat berupa nasihat, petunjuk, saran-saran atau umpan balik.

\section{Metode penelitian}

Metode pengumpulan data dalam penelitian ini menggunakan metode kuantitatif. Penerimaan diri sebagai variabel dependen dan dukungan sosial keluarga sebagai variabel independen. Alat ukur untuk mengumpulkan data menggunakan skala penerimaan diri dan skala dukungan sosial keluarga. Skala yang dipakai terlebih dahulu dilakukan uji coba pada subjek yang memiliki karakteristik-karakteristik yang sama pada populasi penelitian, hasil dari uji coba digunakan untuk menguji validitas dan reliabilitas alat ukur yang dipakai sehingga skala dapat digunakan dalam penelitian. Subjek penelitian terdiri dari 112 santri kelas X dan XI yang tinggal di pondok pesantren. Analisis yang digunakan dalam penelitian ini adalah metode statistik dengan teknik analisis product moment yang berbasis program SPSS IBM 23 for windows.

\section{Hasil dan Pembahasan}

Penelitian ini koefesien reliabelitas yang diharapkan adalah 0,7. Skala penerimaan diri memiliki koefesien reliabilitas alpha (a) sebesar 0, 849 dan skala dukungan sosial keluarga memiliki koefesien reliabilitas alpha (a) sebesar 0,801. Hasil analisis reliabilitas menunjukan bahwa skala tersebut dapat digunakan sebagai alat pengumpulan data dalam penelitian karena memiliki keadaan yang baik maka selanjutnya dapat dilakukan uji normalitas, uji linearitas, dan uji hipotesis.

Tabel 1. Uji Normalitas

\begin{tabular}{lcrl}
\hline Variabel & Skor KS-Z & $\begin{array}{r}\text { Sig } \\
(\mathrm{p})\end{array}$ & Keterangan \\
\hline Penerimaan diri & 0,856 & 0,457 & Normal \\
Dukungan sosial keluarga & 0,958 & 0,318 & Normal \\
\hline
\end{tabular}

Berdasarkan hasil uji normalitas tersebut maka dapat disimpulkan bahwa masing-masing variabel peneltian memiliki sebaran data yang terdistribusi normal. 
Tabel 2. Uji Linearitas

\begin{tabular}{lccc}
\hline \multicolumn{1}{c}{ Variabel } & $\begin{array}{c}\text { Deviation From } \\
\text { Linearity }(\mathrm{F})\end{array}$ & $\begin{array}{c}\text { Signifikansi } \\
\text { Linearity }(\mathrm{p})\end{array}$ & Keterangan \\
\hline $\begin{array}{l}\text { Penerimaan diri dengan } \\
\text { dukungan sosial keluarga }\end{array}$ & 87.440 & 0.000 & Linear \\
\hline
\end{tabular}

Hasil analisis uji linieritas diatas dapat disimpulkan bahwa ada hubungan yang linier antara variabel penerimaan diri dengan dukungan sosial keluarga. selanjutnya uji hipotesis uji hipotesis yang digunakan dalam penelitian ini dilakukan dengan analisis product moment untuk menguji hubungan antara dukungan sosial keluarga terhadap penerimaan diri.

Tabel 3. Uji Hipotesis

\begin{tabular}{lllllll}
\hline Variabel & & \multicolumn{1}{c}{$\mathrm{r}^{2}$} & Sig $(\mathrm{p})$ & Keterangan \\
\hline $\begin{array}{l}\text { Dukungan sosial } \\
\text { penerimaan diri }\end{array}$ & keluarga & dengan & 0,673 & 0,453 & 0,000 & $\begin{array}{l}\text { Ada hubungan } \\
\text { yang sangat } \\
\text { signifikan }\end{array}$ \\
\hline
\end{tabular}

Terdapat hubungan antara dukungan sosial keluarga dengan penerimaan diri menunjukan bahwa nilai $\mathrm{r}$ $=0,673$ dan taraf signifikansinya $0,000(\mathrm{p}<0,01)$ yang dapat disimpulkan bahwa hipotesis yang diajukan dapat diterima, yang artinya ada hubungan yang sangat signifikan antara dukungan sosial keluarga dan penerimaan diri pada santri pondok pesantren, semakin tinggi dukungan sosial keluarga maka semakin tinggi juga penerimaan diri pada santri pondok pesantren

Hasil korelasi product moment (zero order) menunjukan bahwa terdapat hubungan antara dukungan sosial keluarga dengan penerimaan diri dilihat dari nilai $r=0,673$ dan taraf signifikansinya sig $=0,000$ ( $\mathrm{p}<0,01)$ yang artinya ada hubungan yang sangat signifikan antara dukungan sosial keluarga dan penerimaan diri pada santri pondok pesantren, semakin tinggi dukungan sosial keluarga maka semakin tinggi juga penerimaan diri pada santri pondok pesantren. Sumbangan efektif variabel dukungan sosial keluarga terhadap penerimaan diri sebesar $19,51 \%$ sisanya dipengaruhi oleh variabel lain diluar dari penelitian ini.

Penelitian yang telah dilakukan juga menunjukan bahwa terdapat hubungan yang bersifat positif atau selaras yang signifikan antara dukungan sosial dengan penerimaan diri, hal ini menunjukkan bahwa semakin tinggi dukungan sosial maka semakin tinggi penerimaan diri dan sebaliknya semakin rendah dukungan sosial maka semakin rendah penerimaan diri remaja [7]. Penelitian yang dilakukan oleh Rahma dan Rahayu [15] hasil ini juga memperlihatkan bahwa interaksi yang dilakukan oleh anggota keluarga dalam bentuk dukungan sosial seperti bantuan materi dan nonmateri, perhatian, kepedulian, empati, pemberian saran, nasihat, dan informasi mampu menolong individu untuk mengatasi masalahnya. Penelitian yang telah dilakukan menunjukan bahwa bahwa dukungan sosial yang menyentuh kebutuhan emosional khususnya pengakuan akan kemampuan dan kualitas diri sehingga siswa merasa menerima penghargaan dan kasih sayang orang tua memiliki makna yang besar bagi siswa. Hal ini menunjukkan pentingnya pemenuhan kebutuhan siswa terhadap kebutuhan perhatian dan afeksi dari orang tua yang dapat memunculkan energi positif bagi siswa. Manfaat dukungan sosial dari orang yang dipercaya akan merasa dirinya diperhatikan, dihargai, serta merasa dicintai. Individu yang menerima dukungan sosial akan merasa senang, merasa diberikan bantuan orang lain berdasarkan dari hubungan formal atau informal. Adanya dukungan sosial khususnya dari orang tua akan memberikan kenyamanan fisik dan psikologis bagi anak. Karena dengannya anak akan merasa dicintai, diperhatikan, dihargai oleh orang lain dalam hal ini orang tuanya. [16].

Berdasarkan penelitian yang dilakukan [17], manfaat dukungan sosial, dapat meningkatkan kepercayaan diri siswa dalam meraih prestasi akademik siswa yang menjadi subjeknya. Memberikan dukungan sosial tidak hanya memberikan suatu dukungan akan tetapi memberikan sebuah motivasi serta sebuah informasi yang dibutukan oleh individu juga sangat penting, sehingga individu akan lebih mudah untuk mencapai keinginannya [18]. Adanya dukungan sosial dapat mencegah timbulnya kecemasan pada individu. Dukungan dari orang-orang terdekat berupa kesediaan untuk 
mendengarkan keluhan-keluhan remaja akan membawa efek positif yaitu sebagai pelepasan emosi, meningkatkan harga diri, meningkatkan kepercayaan diri dan mengurangi kecemasan [19]

Kategorisasi 112 subjek pada variabel penerimaan diri memperoleh hasil mayoritas subjek memiliki penerimaan diri yang tinggi. Hal ini karena subjek mimiliki kemampuan dan kemauan untuk membiarkan orang lain melihat jati diri seseorang, subjek juga mampu mengevaluasi diri yang tepat dan mampu melakukan pengambilan keputusan. Penelitian terdahulu berpendapat bahwa penerimaan diri perlu dimiliki oleh setiap individu, Individu yang dapat menerima dirinya dan beberapa aspek hidupnya, tentu tidak akan kesulitan dalam menjalankan kehidupannya karena selalu bersyukur terhadap apa yang dimilikinya [13]. Penelitian yang juga dilakukan oleh Legistini, Flurentin, dan Ramli, Kegagalan individu dalam menerima diri dapat berdampak besar terhadap proses interaksi dengan lingkungan sekitar atau teman sebayanya [20]. Kategorisasi dukungan sosial keluarga 112 subjek memperoleh hasil mayoritas subjek memiliki penerimaan diri yang tinggi berdasarkan aspek dukungan emosional, dukungan penghargaan, dukungan instrumental dan dukungan informasi. Hal ini sejalan dengan penelitian oleh Aziz, orang yang mendapatkan dukungan sosial yang tinggi dari lingkungan sosialnya maka akan banyak mendapatkan dukungan emosional, penghargaan, instrumental, dan informatif dari keluarga [21]. Aziz juga menambahkan, apabila dukungan emosional tinggi individu akan merasa mendapatkan dorongan yang tinggi dari anggota keluarganya. Apabila penghargaan untuk individu tersebut besar, maka akan dapat meningkatkan kepercayaan diri pada individu. Apabila individu memperoleh dukungan instrumental, akan merasa dirinya mendapat fasilitas yang memadai dari keluarga. Apabila individu memperoleh dukungan informatif yang banyak, akan inidvidu itu merasa memperoleh perhatian dan pengetahuan.

\section{Kesimpulan}

Berdasarkan hasil analisis data penelitian maka dapat disimpulkan bahwa dapat disimpulkan bahwa ada hubungan yang sangat signifikan antara dukungan sosial keluarga dan penerimaan diri pada santri pondok pesantren, semakin tinggi dukungan sosial keluarga maka semakin tinggi juga penerimaan diri pada santri pondok pesantren. Penelitian yang telah dilakukan tentang hubungan dukungan sosial keluarga terhadap penerimaan diri pada santri pondok pesantren maka peneliti memberikan saran pada orang tua, agar mampu memberikan dukungan kepada santri yang berada dipondok pesantren. Kepada guru-guru di sekolah diharapkan mampu memotivasi dan mendorong setiap santri dalam pengembangan diri. Untuk peneliti selanjutnya diharapkan agar mampu mengembangkan analisis hasil penelitian menggunakan metode penelitian yang lain selain regresi

\section{Daftar Rujukan}

[1] Suntrock, John W., 2011. Perkembangan anak. Jakarta: Erlangga

[2] Buss, A. 2001., Psychological dimension of the Self. New york: SAGE Publications Thousand sOaks

[3] Hurlock, E. B., 2006. Psikologi Perkembangan Suatu Pendekatan Sepanjang Rentang Kehidupan. Edisi kelima. Alih bahasa Istiwidayanti dan Soedjarwo. Jakarta: Erlangga.

[4] Taylor, S.E., 2012. Health psychology (8th ed.). New York: McGraw Hill, International Edition.

[5] Katc \& Kahn., 2000. The psychology of the peacekeeper: lessons from the field. Greenwood Publishing Group.

[6] Utami, N. M. S. N., 2013. Hubungan antara dukungan sosial keluarga dengan penerimaan diri individu yang mengalami asma. Jurnal Psikologi Udayana, 1 (1), pp.12-21.

[7] Sari, D, J \& Reza, M., 2013. Hubungan antara dukungan sosial dengan penerimaan diri pada remaja penderita HIV di Surabaya. Character, 01 (03), pp. 1-7

[8] Germer, C. K., 2009. The mindful path to self-compassion. United State of America: The Guilford Press

[9] Hurlock, E.B., 2005. Perkembangan anak (jilid 1). Jakarta: Erlangga

[10] Carson, H.S., \& Langer, J.E., 2006. Mindfulness and self-acceptance. Journal of RationalEmotive \& Cognitive-Behavior Therapy, 24(1), pp. 29-43 
[11] Reber, S.A., Reber, S.E. 2010. Kamus Psikologi. Yogyakarta: Pustaka Pelajar

[12] King, L. A., 2012. Psikologi Umum : Sebuah Pandangan Apresiatif Buku 2. Jakarta: Salemba Humanika.

[13] Hartati, J, Erlamsyah, \& Syahniar. 2013. Hubungan antara perlakuan orangtua dengan penerimaan diri siswa. Jurnal Ilmiah Konseling, 2 (1), pp.338-346

[14] Sarafino, E.P \& Smith, T. W. (2014). Health Psychology: Biopsychososial interactions. USA: Wiley

[15] Rahma, U \& Rahayu, E W., 2018. Peran dukungan sosial keluarga dalam membentuk kematangan karier siswa smp. Jurnal Ilmu Keluarga \& Konseling, 11 (3), pp.194 - 205

[16] Maslihah, Sri., 2011. Studi tentang hubungan dukungan sosial, penyesuaian sosial di lingkungan sekolah dan prestasi akademik siswa smpit assyfa boarding school subang jawa barat. Jurnal Psikologi Undip, 10 (2), pp.103-114.

[17] Kusrini dan Prihartani (2014). Hubungan Dukungan Sosial dan Kepercayaan Diri dengan Prestasi Bahasa Inggris Siswa Kelas VIII SMP Negeri 6 Boyolali. Jurnal Penelitian Humaniora, 15, 2. 131-140.

[18] Rokhimah, S. (2014). Pengaruh dukungan sosial dan efikasi diri terhadap minat melanjutkan pendidikan ke perguruan tinggi pada siswa SMA Negeri 1 Tenggarong Seberang. Psikoborneo: Jurnal Ilmiah Psikologi, 2(3), pp. 149-156

[19] Sekarina, D. P., \& Indriana, Y. (2020). Hubungan antara dukungan sosial orangtua dengan kecemasan menghadapi dunia kerja pada siswa kelas xii smk yudya karya magelang. Jurnal Empati, 7(1), pp.381-386.

[20] Legistini, L., Flurentin, E., \& Ramli, M., 2020. Hubungan antara konsep diri dan interaksi sosial dengan penerimaan diri siswa di SMA negri 10 Malang. In prosiding seminar nasional bimbingan dan konseling universitas negeri Malang, Malang Agustus 2020.

[21] Aziz, A., 2016. Hubungan dukungan sosial dengan self legurated learning pada siswa SMA yayasan perguruan Bandung Tembung. Jupiis. Jurnal pendidikan ilmu-ilmu sosial, 8 (2), pp.103-113 